\title{
Loss of DPP4 activity is related to a prothrombogenic status of endothelial cells: implications for the coronary microvasculature of myocardial infarction patients
}

\author{
Paul A. J. Krijnen · Nynke E. Hahn • Ivana Kholová • Umit Baylan • \\ Jessica A. Sipkens · Floris P. van Alphen - Alexander B. A. Vonk • \\ Suat Simsek · Christof Meischl · Casper G. Schalkwijk · Jaap D. van Buul • \\ Victor W. M. van Hinsbergh • Hans W. M. Niessen
}

Received: 16 August 2011/Revised: 15 November 2011/Accepted: 30 November 2011/Published online: 14 December 2011

(C) The Author(s) 2011. This article is published with open access at Springerlink.com

\begin{abstract}
Pro-coagulant and pro-inflammatory intramyocardial (micro)vasculature plays an important role in acute myocardial infarction (AMI). Currently, inhibition of serine protease dipeptidyl peptidase 4 (DPP4) receives a lot of interest as an anti-hyperglycemic therapy in type 2 diabetes patients. However, DPP4 also possesses anti-thrombotic properties and may behave as an immobilized anti-coagulant on endothelial cells. Here, we studied the expression and activity of endothelial DPP4 in human myocardial infarction in relation to a prothrombogenic endothelial phenotype. Using (immuno)histochemistry, DPP4 expression and activity were found on the endothelium of intramyocardial blood vessels in autopsied control hearts $(n=9)$. Within the infarction area of AMI patients $(n=73)$, this DPP4 expression and activity were significantly decreased, coinciding with an increase in Tissue
\end{abstract}

P.A.J. Krijnen and N.E. Hahn contributed equally to this manuscript.

P. A. J. Krijnen $(\bowtie) \cdot$ N. E. Hahn · U. Baylan .

J. A. Sipkens - C. Meischl · H. W. M. Niessen

Department of Pathology, VU University Medical Center,

De Boelelaan 1117, 1007 MB Amsterdam, The Netherlands

e-mail: paj.krijnen@vumc.nl

P. A. J. Krijnen · N. E. Hahn · U. Baylan ·

J. A. Sipkens - A. B. A. Vonk - C. Meischl .

V. W. M. van Hinsbergh - H. W. M. Niessen

ICaR-VU, Amsterdam, The Netherlands

I. Kholová

Department of Pathology, University of Kuopio,

Kuopio, Finland

F. P. van Alphen - J. D. van Buul

Department Molecular Cell Biology, Sanquin Research,

Landsteiner Laboratory, Academic Medical Center,

University of Amsterdam, Amsterdam, The Netherlands
Factor expression. In primary human umbilical vein endothelial cells (HUVECs), Western blot analysis and digital imaging fluorescence microscopy revealed that DPP4 expression was strongly decreased after metabolic inhibition, also coinciding with Tissue Factor upregulation. Interestingly, inhibition of DPP4 activity with diprotin A also enhanced the amount of Tissue Factor encountered and induced the adherence of platelets under flow conditions. Ischemia induces loss of coronary microvascular endothelial DPP4 expression and increased Tissue Factor expression in AMI as well as in vitro in HUVECs. Our data suggest that the loss of DPP4 activity affects the antithrombogenic nature of the endothelium.

Keywords DPP4 - Acute myocardial infarction - Tissue Factor $\cdot$ ROS $\cdot$ Coagulation $\cdot$ Platelet adhesion

A. B. A. Vonk - H. W. M. Niessen

Department of Cardiac Surgery, VU University Medical Center, Amsterdam, The Netherlands

S. Simsek

Department of Internal Medicine, Medical Center Alkmaar, Alkmaar, The Netherlands

C. G. Schalkwijk

Department of Internal Medicine, University of Maastricht, Maastricht, The Netherlands

V. W. M. van Hinsbergh

Department of Physiology, VU University Medical Center, Amsterdam, The Netherlands 


\section{Introduction}

Research on coronary perfusion and restoration thereof after acute myocardial infarction (AMI) has largely been focused, for obvious reasons, on the larger branches of the coronary vasculature located on the epicardium. In the last two decades, however, the role of the smaller intramyocardial microvasculature has gained significant interest. Dysfunction of the intramyocardial microvasculature, specifically the endothelium, following AMI is suggested to relate to left ventricle remodeling, contractility and cardiac events, such as reinfarction and death $[6,9,18,40]$. Also, hindered perfusion of the ischemic myocardium after restoration of coronary flow, known as no-reflow or coronary microvascular obstruction (MVO), might point to dysfunctional coronary microvasculature and associates with larger infarct size and poor clinical outcome [29,39].

A multitude of factors may contribute to MVO including vasospasms, distal embolization, capillary plugging [24, 31]. A role for in situ thrombosis in MVO is debated [31], but the extrinsic (Tissue Factor-dependent) coagulation pathway was shown to play a role in MVO in rabbits [21, 22]. We have reported on structural and functional aberrations of the coronary microvasculature in AMI patients such as basement membrane thickening, adhesion molecule accumulation and products of non-enzymatic glycation (AGEs), as markers of a pro-inflammatory endothelium [3, 8]. It was also shown that a pro-inflammatory phenotype of the coronary microvasculature can induce cardiac fibrosis [28]. A post-AMI shift towards a more pro-inflammatory and pro-coagulant endothelial phenotype may therefore be involved in reduced coronary flow. During our studies we observed unexpectedly - as presented below-a marked decrease of microvascular endothelial dipeptidyl peptidase 4 (DPP4) expression in recently infarcted human hearts.

DPP4, also known as CD26, is expressed by microvascular endothelial cells in humans (i.e. in liver, spleen, lungs and brain) and in the hearts of rats [23, 34]. This serine exopeptidase terminally digests proteins and peptides containing proline in the penultimate position [10]. Its substrates include at least nine chemokines, neuropeptide $\mathrm{Y}$ and glucagon-type peptide-1 (GLP-1) [15, 23, 52]. Because it inactivates GLP-1, inhibition of DPP4 receives a lot of continuing interest as an anti-hyperglycemic therapy in type 2 diabetes [15]. In addition, recent publications suggest cardioprotective properties for GLP-1 analogues and pharmaceutical or genetic inhibition of DPP4 in different animal models of AMI [27, 47].

On the other hand, another known DPP4 substrate is fibrin and via cleaving N-terminal Gly-Pro from the fibrin $\alpha$-chain, DPP4 can inhibit fibrin polymerization and clot formation [25, 42]. As such DPP4 may behave as an immobilized anti-coagulant on (microvascular) endothelium. Consequently, we asked ourselves whether the loss of coronary microvascular DPP4 after AMI relates to the endothelial phenotype shift towards a more pro-coagulant state and the induction of situ thrombosis as a possible inducer of MVO after AMI.

In the present study we evaluated a putative relation between DPP4 expression and pro-coagulant microvasculature in the infarcted human heart and the occurrence of thrombi in the coronary microvasculature. In addition, DPP4 activity was studied in relation to platelet adhesion in human umbilical vein endothelial cells (HUVECs).

\section{Methods}

Patients

A total of 82 autopsied patients were included in the study (Table 1). 73 Patients showed a recently developed left ventricular AMI [decreased lactate dehydrogenase (LDH) staining of the affected myocardium]. Nine patients who died without heart disease were included as controls. Sampling for (immuno)histochemical analysis was performed as in [3]. From the excised hearts $1 \mathrm{~cm}$ cross sections were made. In these cross sections the infarction area was determined using lactate dehydrogenase (LDH) staining. From each AMI patient, a sample of heart tissue was taken from the center of the LDH-determined infarction area and a sample was taken from the non-infarcted right ventricle as an internal control. In control patients a tissue sample was taken from the anterior wall of the left ventricle. The study protocol was approved by the ethics committee of the VU Medical Center, and executed according to the principles of the Declaration of Helsinki.

Microscopic criteria [36] were used to estimate infarct duration and to categorized into five phases of infarction: early phase, PMN (polymorphonuclear neutrophils) phase, chronic phase infarctions, early phase reinfarctions (chronic phase as well as early phase morphology) and $P M N$-phase reinfarctions (chronic phase as well as $P M N$ phase morphology) and corresponded with the clinical evaluation of AMI.

\section{DPP4 enzymatic activity}

A histochemical azo-coupling reaction was performed on $5 \mu \mathrm{m}$ frozen heart tissue sections to identify DPP4 enzymatic activity. The slides were fixed in chloroform and acetone $(1: 1 \mathrm{v} / \mathrm{v})$ and were incubated with the substrate glycyl-proline-4-beta-naphthylamide (Sigma St. Louis, MO, USA) dissolved in $\mathrm{N}, \mathrm{N}$-dimethylformamide (Merck, Haarlem, The Netherlands) and the azo-dye Fast Blue BB Salt (G.T. Gurr Ltd, London, UK) dissolved in PBS, fixed 
Table 1 Patient characteristics

\begin{tabular}{lllll}
\hline & $n$ & Infarct duration & Male/female* & ${\text { Age range }(\mathrm{mean} \pm \mathrm{SE})^{\dagger}}^{*}$ \\
\hline Control & 9 & $\mathrm{NA}$ & $2 / 7$ & $58-86(68 \pm 5)$ \\
Early-phase infarction & 15 & $0-12 \mathrm{~h}$ & $14 / 1$ & $23-88(65 \pm 4)$ \\
PMN-phase infarction & 20 & $12 \mathrm{~h}-5$ days & $15 / 5$ & $47-85(73 \pm 2)$ \\
Chronic-phase infarction & 10 & $5-14$ days & $8 / 2$ & $42-93(68 \pm 4)$ \\
Early-phase reinfarction & 16 & $5-14$ days $+0-12 \mathrm{~h}$ & $12 / 4$ & $45-85(66 \pm 3)$ \\
PMN-phase reinfarction & 12 & $5-14$ days $+12 \mathrm{~h}-5$ days & $10 / 2$ & $30-85(65 \pm 5)$ \\
\hline
\end{tabular}

$n=$ number of patients, $N A=$ not applicable, $P M N$ polymorphonuclear neutrophil

* The male/female composition did not differ significantly between the groups (Chi-square test with ordinal gamma test); ${ }^{\dagger}$ there was no statistical difference in age between the groups (one-way Anova)

again in $4 \%$ formalin mounted in Immu-mount (Shandon, Dreieich, Germany) and analyzed for the percentage of vessels positive for DPP4 activity.

Primary antibodies

For immunohistochemistry the following antibodies were used: mAb against DPP4 (1:100) (Serotec, Oxford, UK), mAb against CD31 (1:40) (Dako, Glostrup, Denmark), mAb against CD68 (1:400) (Dako), mAb against Tissue Factor (1:50) (Acris, Herford, Germany), and mAb against complement factor C3d $(1: 1,500)$ [36]. For digital imaging microscopy the following antibodies were used: $\mathrm{mAb}$ against DPP4 (1:100) (Serotec), mAb against Tissue Factor (1:50) (Acris) and pAb against nitrotyrosine (1:50) (Invitrogen Corporation, Carlsbad, CA, USA). For Western blot analysis the following antibodies were used: $\mathrm{mAb}$ against DPP4 (1:100) (Serotec) and mAb against Tissue Factor (1:50) (Acris). For all Abs PBS controls (Fig. 1a, right panel) and irrelevant Abs (IgG1), tested at similar concentrations, were negative.

\section{Immunohistochemistry}

Cryostat sections $(5 \mu \mathrm{m})$ were fixed in chloroform and acetone (1:1 v/v) and blocked by $3 \%(\mathrm{v} / \mathrm{v}) \mathrm{H}_{2} \mathrm{O}_{2} / \mathrm{PBS}$. Serial slides were incubated in normal rabbit serum (Dakopatts) [1:50 in 1\% (w/v) BSA/PBS], incubated with primary antibodies (in BSA/PBS), incubated with rabbitanti-mouse-HRP (Dakopatts) (1:25 in BSA/PBS), incu-

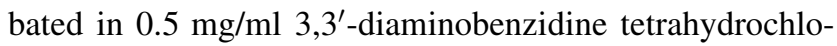
ride (DAB, Sigma, St. Louis, MO, USA) in $0.01 \%(\mathrm{v} / \mathrm{v})$ $\mathrm{H}_{2} \mathrm{O}_{2} / \mathrm{PBS}$ and counterstained with hematoxylin.

Three investigators (P.A.J.K., N.H. and I.K.) independently scored all slides. The total number of blood vessels was determined with CD31. The percentage of DPP4- and Tissue Factor-positive blood vessels was then determined and equated for slide areas.
Cell culture

Freshly isolated HUVECs were cultured in M199 culture medium containing heat-inactivated human serum $(10 \%$ $\mathrm{v} / \mathrm{v})$, fetal calf serum $(10 \% \mathrm{v} / \mathrm{v}), 2,500$ Units heparin and $100 \mu \mathrm{g} / \mathrm{ml}$ endothelial cell growth factor (cells cultured in this medium served as controls). For metabolic inhibition, cells were incubated in $0.9 \mathrm{mM} \mathrm{CaCl} \mathrm{Cl}_{2} \cdot \mathrm{H}_{2} \mathrm{O}, 20 \mathrm{mM}$ 2-deoxy-D-glucose (Sigma, St. Louis, MO, USA), $106 \mathrm{mM}$ $\mathrm{NaCl}, 5 \mathrm{mM} \mathrm{NaCN}, 3.8 \mathrm{mM} \mathrm{NaHCO} 3,4.4 \mathrm{mM} \mathrm{KCl}$ and $1 \mathrm{mM} \mathrm{MgCl}{ }_{2} \cdot \mathrm{H}_{2} \mathrm{O}$ in $\mathrm{H}_{2} \mathrm{O}(\mathrm{pH}$ 6.6). Apocynin $(100 \mu \mathrm{M})$, diprotin A $(10 \mathrm{mM})$, polymyxin $\mathrm{B}$ sulfate $(2 \mu \mathrm{g} / \mathrm{ml})$ and $\mathrm{TNF} \alpha(10 \mu \mathrm{g} / \mathrm{ml})$ (all Sigma) were incubated for $6 \mathrm{~h}$.

\section{Western blotting}

After culturing in culture medium or metabolic inhibition buffer, HUVECs were lysed in buffer containing $0.01 \%$ NP-40, $2.5 \mathrm{mM}$ Tris-HCl, (pH 8.0), $150 \mu \mathrm{M} \mathrm{NaCl}$, and $5 \mathrm{mM}$ EDTA in $\mathrm{H}_{2} \mathrm{O}$. Protein concentration was determined using the BCA protein assay kit (Pierce, Rockford, IL, USA). Then reducing ( $\beta$-mercaptoethanol-containing) sample loading buffer [0.25 M Tris ( $\mathrm{pH}$ 6.8), sodium dodecyl sulfate (SDS), glycerol, 2-mercaptoethanol, bromophenol blue] was added and the samples were mixed and heated at $95^{\circ} \mathrm{C}$ for $5 \mathrm{~min}$. Proteins were separated via electrophoresis and blotted onto nitrocellulose membranes, incubated with primary antibodies, incubated with rabbitanti-mouse-HRP $(1: 1,000)$ and then visualized by Enhanced ChemiLuminescence (ECL; Amersham, Buckinghamshire, UK).

\section{Digital imaging microscopy}

HUVECs were grown in 4-well chamber slides (Nalge Nunc International, Naperville, IL, USA). After treatment, the cells were fixed in $4 \%$ formaldehyde, permeabilized with acetone-methanol (70-30\%), incubated with primary 
Fig. 1 DPP4 in the human myocardium. a DPP4 positivity (left panel; arrows) on the endothelium of intramyocardial blood vessels (asterisks) and a PBS control (right panel) in the heart of a control patient.

Original magnification $\times 125$. b DPP4 (left panel; arrows) and CD31 (right panel; arrows) in capillaries in the heart of a control patient. Original magnification $\times 40$.

c Percentage of blood vessels positive for DPP4 protein (grey bars), and DPP4 activity (black bars) in control patients and in infarctions of all durations. $n$ number of patients. ${ }^{*} p<0.001,{ }^{\dagger} p<0.01$, ${ }^{*} p<0.05,{ }^{\#} p<0.05$, all compared to control. d Percentage of blood vessels positive for DPP4 protein (black bars) control patients and non-infarcted myocardium (right ventricle) of AMI patients
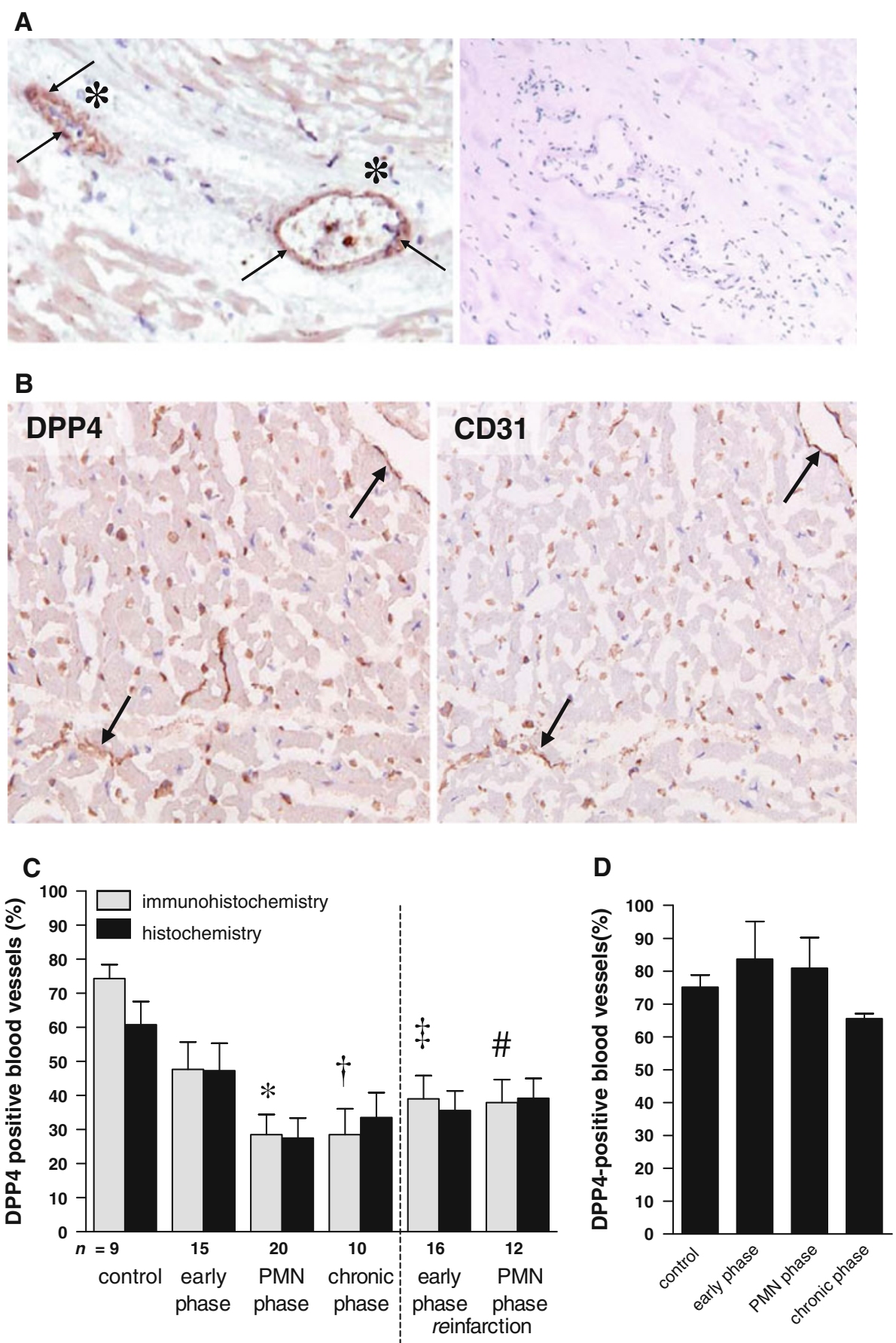

antibodies, incubated with donkey-anti-mouse-Alexa 488 (1:40) (DPP4, Tissue Factor) and/or donkey-anti-rabbitAlexa 647 (1:40) (nitrotyrosine) and incubated with wheat germ agglutinin (WGA), (1:40) (Invitrogen) to visualize cellular membranes (all in 1:2,000 v/v PBS/Tween20). Slides were covered in mounting medium containing DAPI (Vector Laboratories Inc, Burlingame, CA, USA) to visualize nuclei and analyzed with a 3I Marianas ${ }^{\mathrm{TM}}$ digital imaging microscopy workstation (Carl Zeiss, Sliedrecht, Netherlands). To determine cell viability, cells were stained with trypan blue and then quantified. In the digital imaging microscopy experiments on average 70 cells were analyzed per condition per donor.

\section{Platelet isolation}

Whole blood, obtained from healthy individuals, was centrifuged at $150 \times g$. The supernatant was $1: 1$ diluted in $\mathrm{Ca}^{2+}$-free Krebs-Ringer buffer (4 mM KCL, $107 \mathrm{mM}$ $\mathrm{NaCl}, 20 \mathrm{mM} \mathrm{NaHCO} 3,2 \mathrm{mM} \mathrm{Na} \mathrm{SO}_{4}, 19 \mathrm{mM}$ tri-sodium 
citrate, $0.5 \%(\mathrm{w} / \mathrm{v})$ glucose in $\left.\mathrm{H}_{2} \mathrm{O}\right)(\mathrm{pH} 5.0)$ and centrifuged at $500 \times g$. The obtained non-stimulated platelets were labeled with calcein (Invitrogen) diluted 2:1 (w/v) in DMSO and used in a final concentration of $300,000 / \mu \mathrm{l}$ in $\mathrm{Ca}^{2+}$-free Krebs-Ringer flow buffer ( $\mathrm{pH}$ 6.1).

Perfusion of HUVECs with platelets

HUVECs were cultured in fibronectin-coated $\mu$-Slides VI ${ }^{0.4}$ (Ibidi GmbH, Martinsried, Germany) until uniform confluent monolayers were obtained. Prior to perfusion cells were incubated with either culture medium (controls) or with culture medium supplemented with Diprotin A $(10 \mathrm{mM})$ or with $\mathrm{TNF} \alpha(10 \mu \mathrm{g} / \mathrm{ml})$ for $6 \mathrm{~h}$. The slides were connected to two ANTEC syringe pumps [ANTEC (leyden), Zouterwoude, The Netherlands] via a flow kit (Ibidi) to generate a constant flow rate with a shear stress of $0.35 \mathrm{dyne} / \mathrm{cm}^{2}$. The slides were mounted on a Zeiss Axiovert 200m microscope (Zeiss, Göttingen, Germany). The HUVECs were perfused with calcein-labeled platelets for $3 \mathrm{~min}$.

\section{Statistical analysis}

Paired or non-paired $t$ tests, Mann-Whitney analysis, Chisquare test + ordinal Gamma test, Kruskal-Wallis test + Dunns multiple comparison tests or one-way ANOVA + Bonferroni's multiple comparison tests were used when appropriate. In figures, values are given as means \pm standard error. A $p$ value (two-sided) of less than 0.05 was considered to represent a significant difference.

\section{Results}

DPP4 in the human myocardium

In human hearts, DPP4 was found on the endothelium in larger intramyocardial arteries (Fig. 1a) as well as in venules and capillaries (Fig. 1b). Cardiomyocytes were negative for DPP4 in all patients. DPP4 was found in the hearts of control patients as well as in the infarcted myocardium of AMI patients (Fig. 1c, grey bars). However, the percentage of DPP4-positive blood vessels was significantly lower in infarctions of all durations compared with controls, except for early-phase infarctions (PMN phase $p<0.001$, chronic phase $p<0.01$, early- and PMN-phase reinfarctions $p<0.05)$. In early-phase infarctions, the percentage of DPP4-positive blood vessels was markedly lower than in controls, but not significantly. DPP4 expression coincided with enzymatic activity in all infarct durations as well as in controls (Fig. 1c, black bars). Pearson correlation analysis revealed that in the controls and all phases of infarction patients' age did not correlate with the DPP4 expression score: control $\left(r^{2}=0.05167\right)$, early phase $\left(r^{2}=0.01368\right)$, PMN phase $\left(r^{2}=0.1468\right)$, chronic phase $\left(r^{2}=0.001577\right)$, early-phase reinfarction $\left(r^{2}=0.05768\right)$ and chronic-phase reinfarction $\left(r^{2}=\right.$ $0,02594)(p>0.05$ in all groups). Notably, in chronicphase infarctions DPP4 positivity was also observed in blood vessels, lymphocytes and granulation tissue (not shown).

In non-infarcted myocardium from AMI patients, no reduction in the percentage of DPP4-positive blood vessels was found compared to controls (Fig. 1d).

Tissue Factor in the human myocardium

As DPP4 may act as an anti-coagulant enzyme, the expression of pro-coagulant Tissue Factor was analyzed in control hearts and in PMN-phase infarctions and PMNphase reinfarctions.

In control hearts, low levels of Tissue Factor were found in the sub-endothelial layer of a small number of intramyocardial blood vessels (Fig. 2a). Cardiomyocytes were negative for Tissue Factor. In the infarcted myocardium, the percentage of Tissue Factor-positive intramyocardial blood vessels significantly increased (PMN-phase infarctions $p<0.01$, PMN-phase reinfarctions $p<0.001$; Fig. 2a, b). Tissue Factor was found in the endothelial- and subendothelial layer of blood vessels (Fig. 2c, d) as well as on damaged cardiomyocytes that also stained positive for complement (factor C3d, not shown). As macrophages can also express Tissue Factor [13], we examined putative co-localization between macrophage marker CD68 and Tissue Factor. On Tissue Factor-positive endothelial cells no CD68-positive macrophages were found (not shown).

As Tissue Factor is a coagulation initiator we analyzed the presence of thrombi in the intramyocardial (micro)vasculature. We detected CD31-positive thrombi in the lumen of intramyocardial blood vessels in only 5 out of 32 analyzed patients (not shown). In these five patients, the percentage of intramyocardial blood vessels positive for Tissue Factor was higher than in AMI patients without detectable thrombi, although not significant $(p=0.06)$.

DPP4 and Tissue Factor expression in endothelial cells

DPP4 expression was decreased in those parts of the heart that were exposed to ischemia. To investigate whether ischemia by itself can induce the loss of endothelial DPP4, its expression was studied in metabolically inhibited HUVECs via digital imaging microscopy (Fig. 3a-c).

In control cells (Fig. 3aI), DPP4 was abundantly present on the cell surface as well as in the cytoplasm. DPP4 expression was reduced significantly after $3(p<0.001)$ and $6 \mathrm{~h}(p<0.001)$ of metabolic inhibition (Fig. 3aII-III, 
Fig. 2 Tissue Factor expression in the human myocardium. a Percentage of Tissue Factor-positive blood vessels in control patients, PMN-phase infarctions and PMN-phase reinfarctions. $n=$ number of patients. ${ }^{*} p<0.01,{ }^{*} p<0.001$, both compared to control. b Tissue Factor expression in intramyocardial blood vessels (arrows) of a patient with a PMN-phase infarction. Original magnification $\times 40$. c CD31 (top) and Tissue Factor (TF; bottom) expression in intramyocardial blood vessels within the infarcted human heart. Arrows endothelial cells positive for staining. Original magnification $\times 400$

b). These results were verified by Western blot analysis (Fig. 3c). Notably, after 3 and 6 h of metabolic inhibition cell viability was still more that $95 \%$, as determined by trypan blue staining (not shown).

In contrast, Tissue Factor was induced reaching statistical significance after $6 \mathrm{~h}$ of metabolic inhibition $(p<0.001$; Fig. 3dI-III, e).

As exogenous reactive oxygen species (ROS), which are produced also during ischemia, can be involved in endothelial Tissue Factor expression [30], involvement of ROS in ischemia-induced Tissue Factor and/or reduced DPP4 expressions in HUVECs was analyzed via digital imaging fluorescence microscopy. Nuclear ROS significantly increased after $6 \mathrm{~h}$ of metabolic inhibition $(p<0.001$; Fig. 4a). The antioxidant and inhibitor of NADPH oxidasederived ROS apocynin significantly counteracted this increase $(p<0.001$; Fig. 4a) as well as the effects of metabolic inhibition on the expressions of both DPP4 and Tissue Factor $(p<0.001 ;$ Fig. $4 \mathrm{~b}, \mathrm{c})$. These results suggest that the effects induced by metabolic inhibition on DPP4 and Tissue Factor expression involve NADPH oxidasederived ROS.

In addition, the putative effects of DPP4 activity inhibition by diprotin A on nuclear ROS and on Tissue Factor expression were analyzed in HUVECs via digital imaging microscopy. In contrast to metabolic inhibition Diprotin A induced a significant decrease in nuclear ROS $(p<0.001$; Fig. 4d). Remarkably, diprotin A did induce a significant increase in endothelial Tissue Factor expression $(p<0.0001$; Fig. 4e), which was verified via western blot analysis (Fig. 4f). To confirm that the effects of diprotin A on nuclear ROS and Tissue Factor expression were not due to endotoxin contamination, the effects of diprotin A on nuclear ROS and Tissue Factor expression were analyzed in the presence of the endotoxin antagonist polymyxin B. Polymyxin B did not affect the diprotin A-mediated effects (3 independent experiments; not shown).

Inhibition of DPP4 activity induces adherence of platelets to endothelial cells

Aggregation of platelets to endothelial cells is a sign of thrombogenicity. Here we tested whether inhibition of DPP4 activity by diprotin A in HUVECs leads to increased

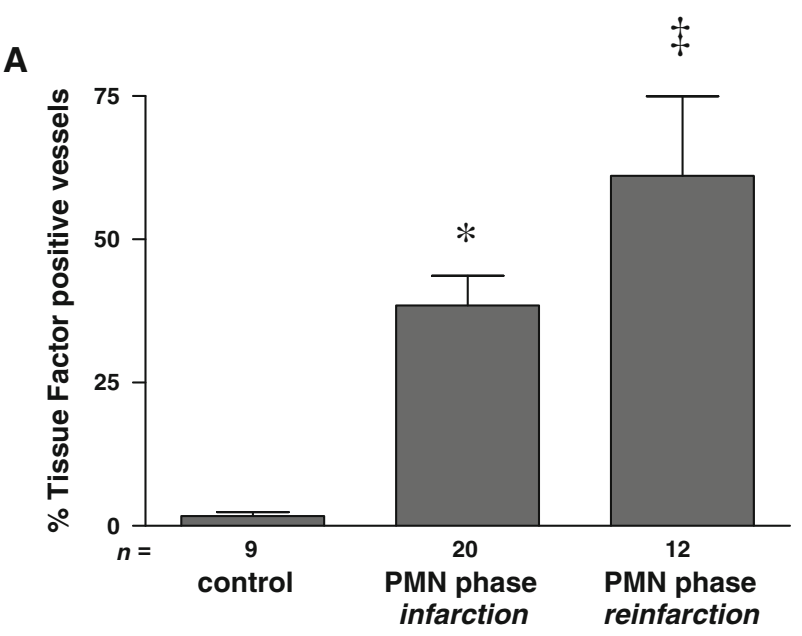

B

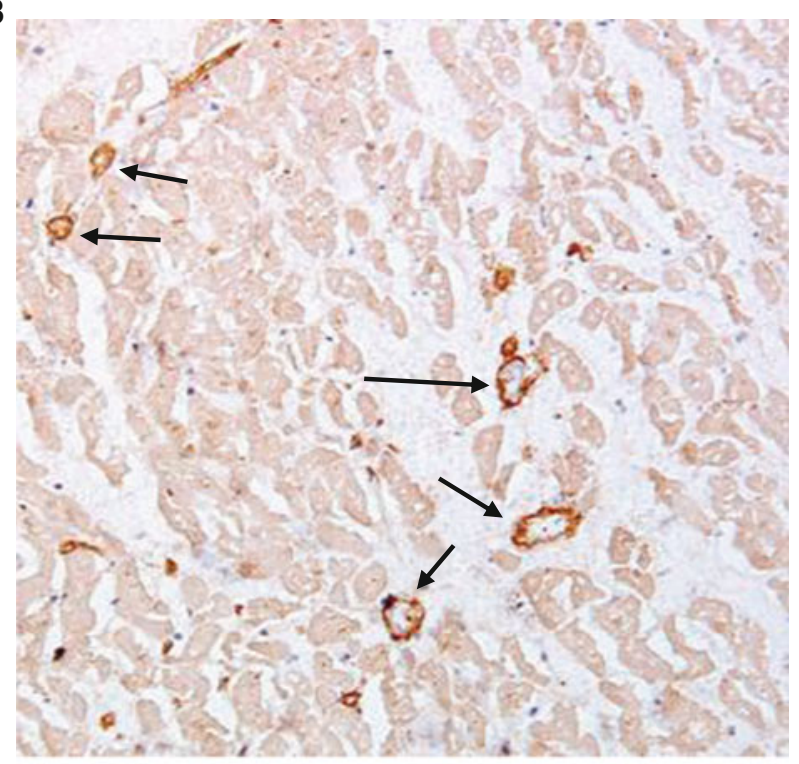

C

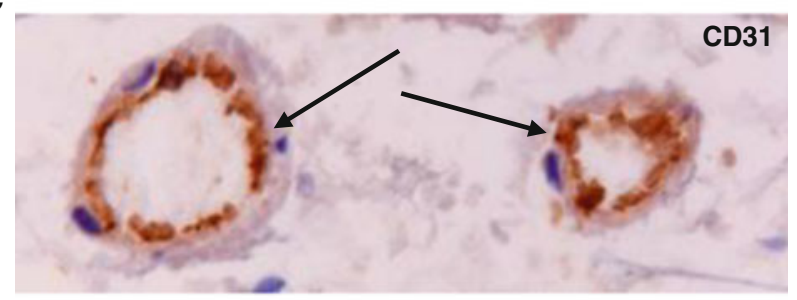

D

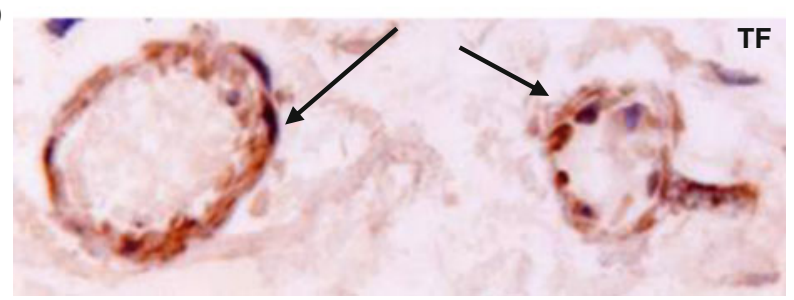

adherence of non-stimulated platelets under flow conditions. Platelet adhesion-inducing $\mathrm{TNF} \alpha$ was used as a positive control [2]. 
Fig. 3 DPP4 and Tissue Factor expression in ischemic HUVECs 3D-digital imaging microscopy images of aI-III DPP4 (green), membranes (WGA red) and nuclei (DAPI blue) and of dI-III Tissue Factor (green), membranes (WGA red) and nuclei (DAPI blue) in control cells and after 3 or $6 \mathrm{~h}$ of metabolic inhibition. Original magnification $\times 40$ $(n=5)$. b Quantification of DPP4 microscopy analysis (relative difference compared to control cells). $* p<0.001$, ${ }^{*} p<0.001$. c Western blot analysis of DPP4 expression in control cells or after 3 or $6 \mathrm{~h}$ of metabolic inhibition. The same amounts of protein were loaded $(n=3)$. e Quantification of the Tissue Factor expression microscopy analysis (relative difference compared to control cells) $* p<0.001$
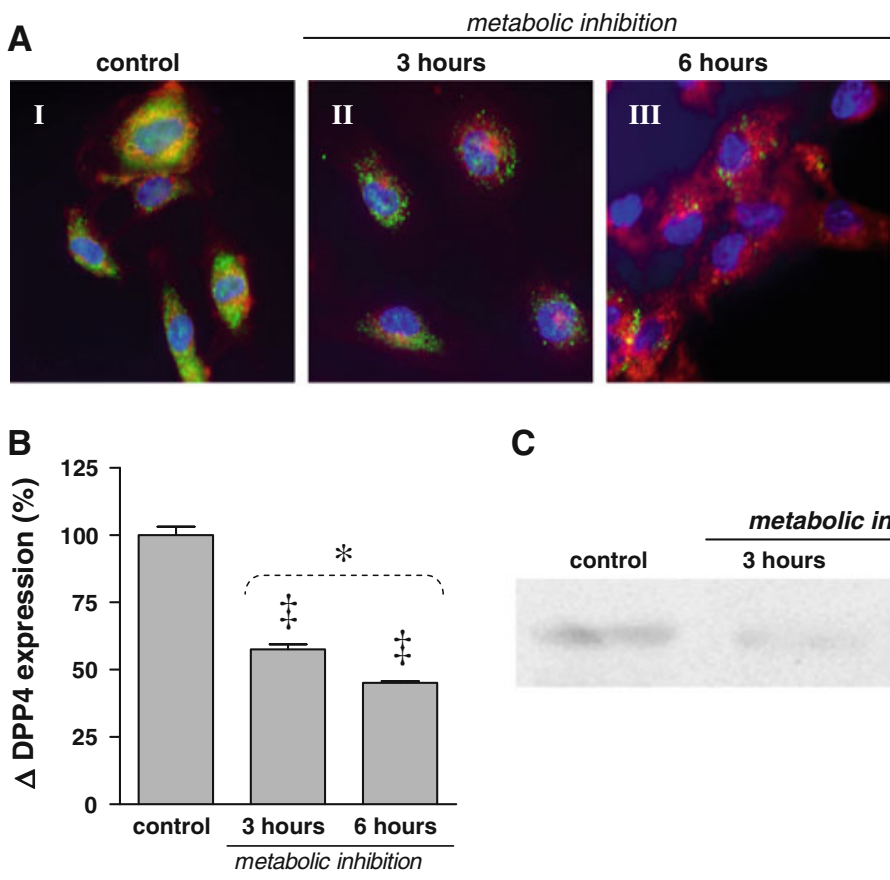

C
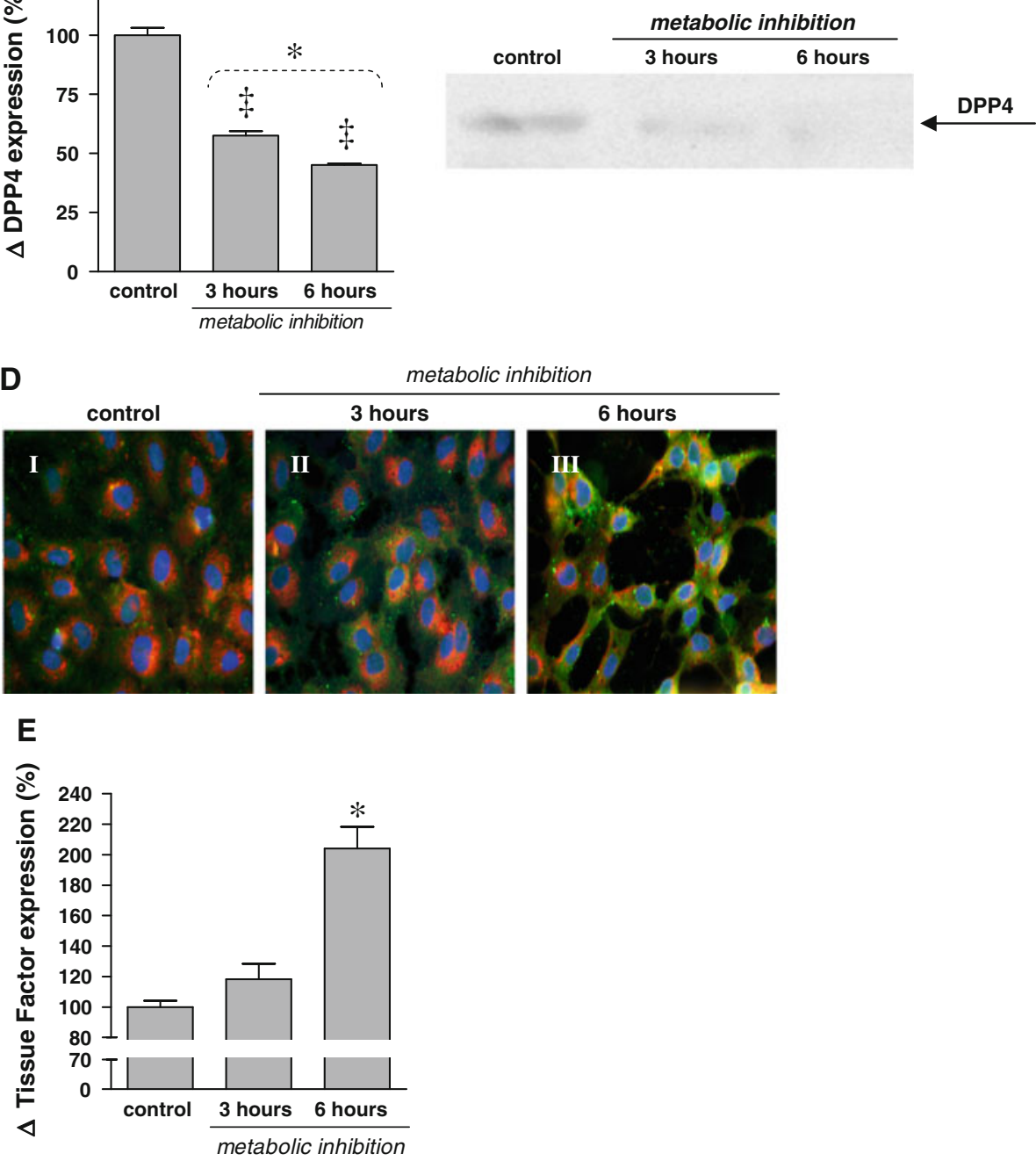

In untreated HUVECs, very few platelets adhered, mainly as solitary cells (upward arrows; Fig. 5a). Unbound platelets were recognized as unfocussed blurred stripes as they passed (dotted arrows). TNF $\alpha$ induced a marked increase in adhering platelets (Fig. 5b). These platelets adhered both individually (upward arrows) and as strings of platelets (downward arrows) of various length, sometimes up to 20 or more platelets per string. These strings were formed within seconds. Aggregation of platelets was not observed. Similarly, diprotin A induced a marked increase in adhering platelets compared to untreated cells (Fig. 5c). Again, platelets adhered both individually (upward arrows) and as strings of platelets (downward arrows), but did not aggregate. Interestingly, the adherence of platelets was in majority temporary in these conditions. Adhered platelets sometimes released after seconds, but most platelets adhered for longer and released after minutes. These results thus indicate that loss of DPP4 activity in endothelial cells can induce a prothrombotic status. 
Fig. 4 Nuclear nitrotyrosine,

Tissue Factor and DPP4

expression in ischemic

HUVECs Using 3D-digital

imaging microscopy, nuclear nitrotyrosine (a), cellular DPP4

(b), and Tissue Factor

(c) expression quantified in control cells or after 3 or $6 \mathrm{~h}$ of metabolic inhibition $(M I)$ with or without apocynin $(100 \mu \mathrm{M})$ (relative difference compared to control cells) $(n=4)$.

a $* p<0.001,{ }^{\dagger} p<0.001$;

b $* p<0.001,{ }^{\dagger} p<0.001$;

c $* p<0.001,{ }^{\dagger} p<0.01$.

3D-digital imaging microscopy

of nuclear nitrotyrosine (d) and cellular Tissue Factor

(e) expression were quantified in HUVECS cultured under control conditions with or without diprotin A $(10 \mathrm{mM})$ for $6 \mathrm{~h}$ (relative difference compared to control cells) $(n=3) . \mathbf{d} * p<0.001$, e $* p<0.0001$. Tissue Factor expression was verified via western blot analysis (f)
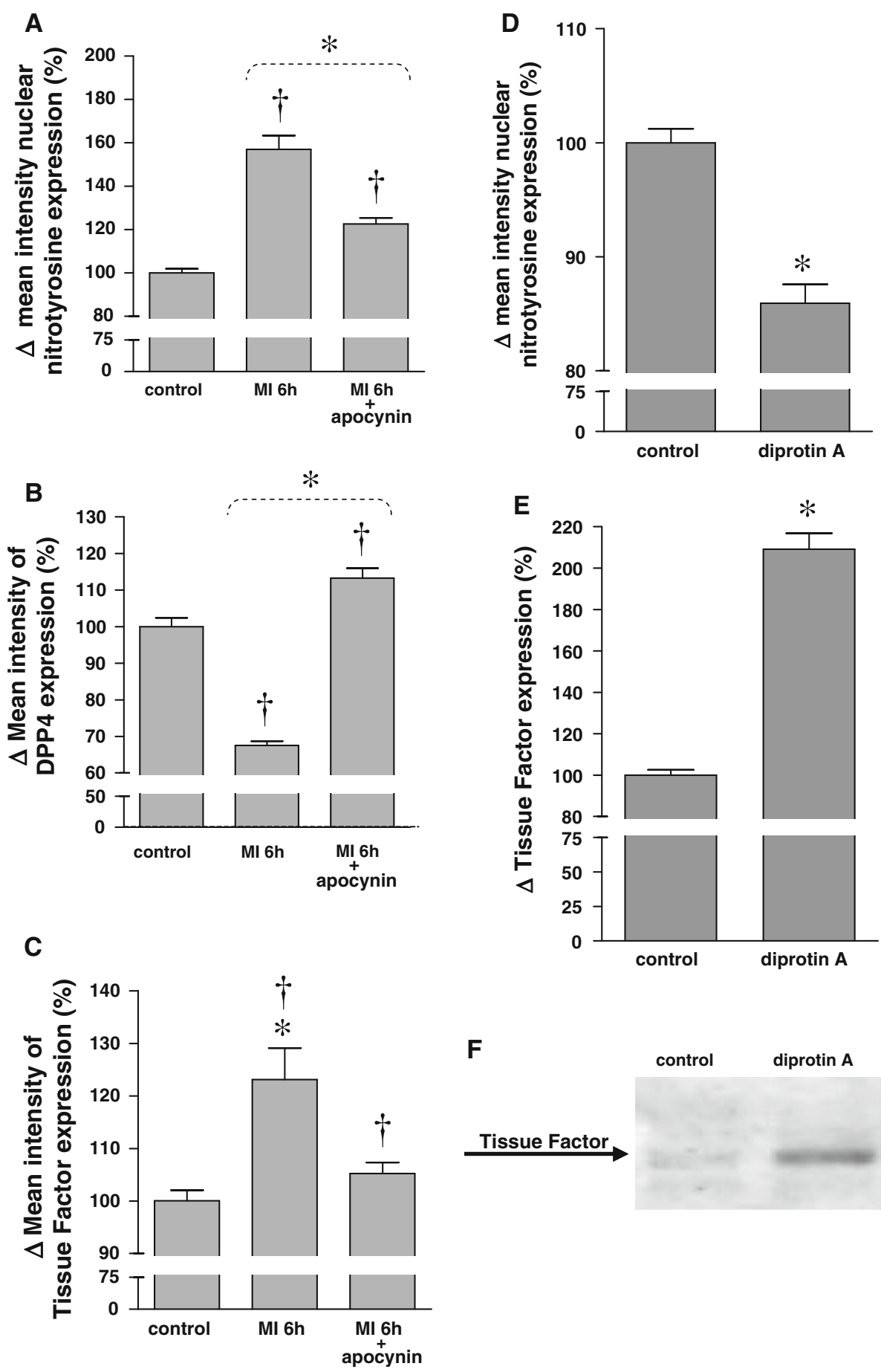

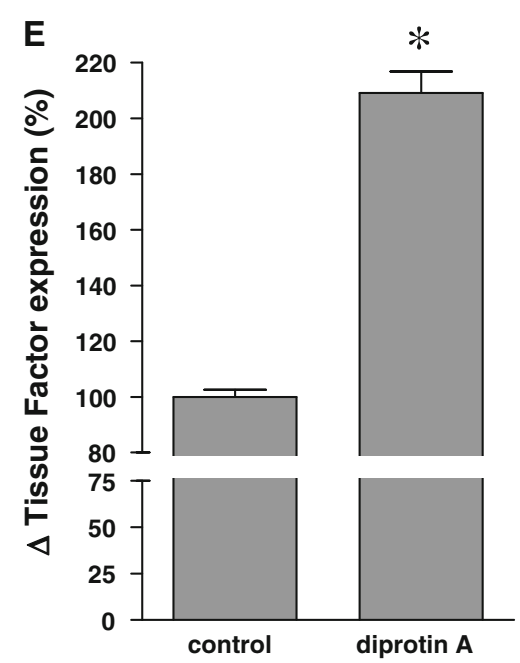

$\mathbf{F}$

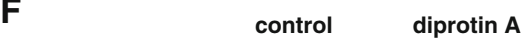

Tissue Factor

\section{Discussion}

Currently, DPP4 receives an attention as a target for antihyperglycemic therapy in type 2 diabetes patients and cardioprotective properties have been ascribed to GLP-1 analogues and to DPP4 inhibition in AMI. However, DPP4 can act as a proteolytic enzyme, a receptor and a costimulatory protein and has been shown to be involved in a wide range of different cellular functions [10]. We now show that enzymatically active DPP4 is expressed by the endothelium of the intramyocardial (micro)vasculature in humans. Interestingly, this DPP4 expression and activity decreased within the infarction area of AMI patients, coinciding with increased microvascular Tissue Factor expression. In HUVECs, metabolic inhibition induced ROS-dependent loss of DPP4 and concomitant Tissue Factor upregulation. And inhibition of DPP4 activity induced adhesion of platelets. Taken together, our data 

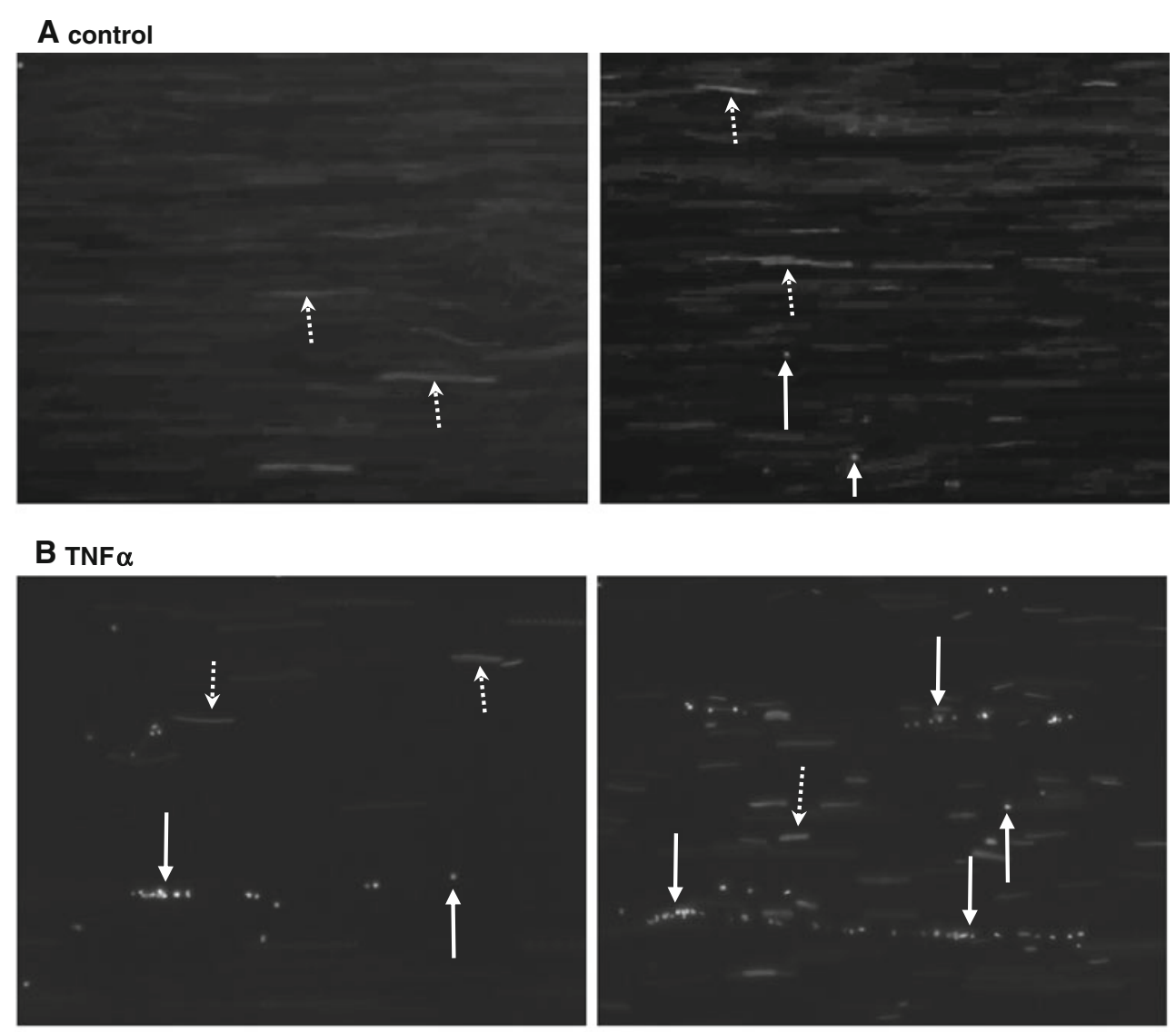

\section{C $\operatorname{diprotin}$ A}
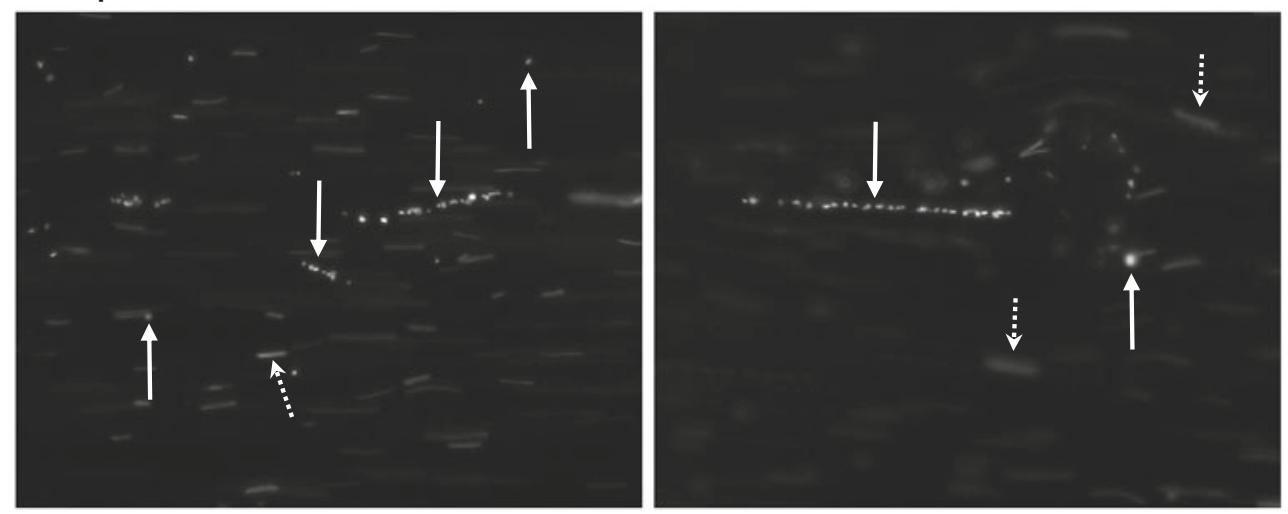

Fig. 5 Diprotin A and $\mathrm{TNF} \alpha$ induced platelet adhesion to HUVECs under perfusion. Example of calcein-labeled platelets adhering to (unstained) HUVECs; under control conditions (a), pre-treated with $\mathrm{TNF} \alpha(\mathbf{b})$ or diprotin A (c) for $6 \mathrm{~h}(n=5)$. Platelets adhered both as

suggest a direct relation between DPP4 activity and thrombogenic status of endothelial cells.

The post-infarct decrease of intramyocardial microvascular DPP4 expression may be a direct result of the ischemia endured or due to enhanced availability of inflammatory cytokines such as $\mathrm{TNF} \alpha$. Involvement of ischemia is supported by our finding that persisting metabolic inhibition markedly reduced DPP4 expression in still

strings (downward solid arrows) as well as individually (upward solid arrows). Non-adhered platelets are recognized as blurred stripes as they pass (dotted arrows)

viable human endothelial cells. This seems at variance with observations in a rat model of hindlimb skeletal muscle ischemia, in which control muscles did not contain DPP4 mRNA at all, and DPP4 mRNA was induced by ischemia [37]. However, neither protein levels nor cellular origin of DPP4 were determined. Furthermore, we observed an increase of DPP4 in blood vessels within granulation tissue in chronic-phase infarctions. Therefore, these differences 
may be related to differences in expression or timing between muscle cells and endothelial cells. Inflammatory cytokines such as TNF $\alpha$ and IL6 were shown to be involved in impaired coronary microvascular perfusion [32, 33, 38, 45, 51]. As TNF $\alpha$ can both reduce DPP4 [48] and induce Tissue Factor $[11,20]$, we cannot exclude that such inflammatory cytokine also may contribute to the effects observed in infarcted hearts [33]. However, it does not contribute to the observations in metabolically inhibited cultured endothelial cells.

Contrary to DPP4, Tissue Factor was upregulated in the infarcted heart, both in the intramyocardial microvasculature as well as in damaged cardiomyocytes. This increase may also result from the ischemia endured, as demonstrated in endothelial cells in vitro. Tissue Factor expression was shown earlier in human and animal hearts and was implicated in mediating reperfusion injury, as Tissue Factor inhibition resulted in decreased inflammation and infarct size in rabbit and mouse AMI models [12, 14, 22]. Tissue Factor, a member of the cytokine receptor superfamily, initiates blood coagulation through the binding of FVII/FVIIa [41]. Additionally, the Tissue Factor/FVIIa complex or Tissue Factor alone can activate different (proinflammatory) cellular signaling pathways $[17,41]$. Tissue Factor inhibition was shown by two independent groups to reduce myocardial infarct size in rabbits, although one group suggested that this was due not through inhibition of thrombotic events but through inhibition of inflammation [12], while the other concluded that it reduced intramyocardial coagulation and reduced the no-reflow phenomenon [22].

Platelet adhesion resulting in microvascular plugging was shown to cause reduced perfusion and no-reflow after AMI [7, 46]. In our in vitro experiments, inhibition of DPP4 activity induced adherence of non-stimulated platelets to HUVECs under flow conditions. Adherence of nonstimulated platelets to cytokine- or microparticle-stimulated endothelial cells was shown before $[1,2,16,26,49$, 53]. It was shown that platelet adhesion can depend on Tissue Factor [49, 53], interactions between platelet F11 receptor and endothelial JAM [2] and on secreted von Willebrand factor (vWf) [1, 16, 26]. It was shown recently that platelet-derived growth factor CC (PDGF-CC), released from activated platelets induced Tissue Factor expression in human microvascular endothelial cells [19]. Although in our platelet adhesion experiments we used non-stimulated platelets we cannot exclude such a role for PDGF-CC. In our experiments, platelets adhered individually and in strings. These strings of platelets indicate a role for $\mathrm{vWf}$, as it was shown earlier that platelets bind endothelial cells through $v W f$ in such fashion $[1,16,26]$.

Therefore, the reduced presence/activity of DPP4 and increased presence of Tissue Factor in the post-MI intramyocardial microvasculature suggests a shift towards a prothrombogenic status of the endothelium and an increased risk of intramyocardial thrombosis. However, in only 5 out of 32 analyzed AMI patients intramyocardial thrombi were found. As thrombolytic treatment is standard procedure for AMI patients, prospective thrombi may dissolve prior to analysis.

The ischemia-induced effects on DPP4 and Tissue Factor expressions were inhibited by the antioxidant and inhibitor of NADPH oxidase-derived ROS apocynin, suggesting ROS involvement in both events. Involvement of ROS in Tissue Factor expression was reported before. In primary endothelial cells exogenous superoxide induced concomitant NADPH oxidase activation and Tissue Factor expression [30] and LPS induced NOX1-mediated Tissue Factor expression [43], whereas PAR1/2-induced endothelial Tissue Factor expression was mediated solely via mitochondrial ROS [5]. Mitochondrial ROS are a potential candidate for involvement in ischemia-induced Tissue Factor expression and possibly ischemia-induced loss of DPP4.

In contrast to ischemia, DPP4 activity inhibition with diprotin A reduced nuclear ROS production. It was recently shown that GLP-1 protected endothelial cells against oxidative stress in vitro [44]. However, in the said study the effects of added GLP-1 on cultured endothelial cells were investigated and since there is no evidence available so far that endothelial cells can produce GLP-1 themselves, it is unlikely that GLP-1 was a factor in our in vitro experiments. Thus, diprotin A most likely reduced ROS independent of GLP-1. Remarkably, diprotin A simultaneously induced a significant increase in endothelial Tissue Factor expression. The fact that diprotin A, even though it lowered nuclear ROS, did induce Tissue Factor, strongly suggests that different cellular pathways are involved in Tissue Factor upregulation induced by ischemia on the one hand (which increased nuclear ROS) and by diprotin A on the other (which lowered nuclear ROS). Whether, and if so to what extent, these different pathways are relevant in the infarcted heart in vivo remains to be established.

Dysfunction of the intramyocardial microvasculature following AMI relates to left ventricular remodeling and cardiac events $[6,9,18]$, may relate to no-reflow of the ischemic myocardium and is associated with larger infarct size and poor clinical outcome [29]. The AMI-induced loss of DPP4 and concomitant Tissue Factor upregulation we show here may contribute to this dysfunction. DPP4 activity was also implicated in revascularization of ischemic tissues via conversion of neuropeptide $Y$ [37, 52]. Our observed DPP4 increase in chronic-phase infarctions in blood vessels within granulation tissue might support such a role. Alternatively, recent studies show evidence for a cardioprotective role for pharmacologic inhibition and of 
genetic depletion of DDP4 in rat- and mouse-myocardial infarction models [27, 35, 47, 50]. These cardioprotective/ infarct size limiting effects of DPP4 inhibition were largely attributed to the prevention of GLP-1 degradation. The cardioprotective effects of increased GLP-1 levels may involve improved glucose uptake, increased myocardial cyclic AMP levels and activation of cardioprotective kinases, such as PKA and AKT [27, 35, 47, 50]. However, Ban et al. [4] showed novel cardiac and vascular protective effects of truncated GLP-1(9-36), suggesting that DPP4 also may have cardioprotective effects through the degradation of GLP-1, but possibly also via the before mentioned angiogenesis-inducing conversion of neuropeptide Y [37, 52]. Therefore, these studies, and the current study, highlight that the roles of DPP4 in the heart may be complex and may have opposing effects. Hence, monitoring of the effects of DPP4 inhibition in patients at risk foror with AMI appears warranted.

In conclusion, we show that DPP4 activity is related to the thrombogenic status of endothelial cells in that lack of DPP4 activity induces expression of Tissue Factor and platelet adhesion, and that this relation may have implications regarding post-AMI dysfunction of the coronary microvasculature.

Acknowledgments Dr. Kholová was a PhD student of the Marie Curie Training Site of the European Community (No. HPMT-2000114) at the ICaR-VU.

Open Access This article is distributed under the terms of the Creative Commons Attribution Noncommercial License which permits any noncommercial use, distribution, and reproduction in any medium, provided the original author(s) and source are credited.

\section{References}

1. Andre P, Denis CV, Ware J, Saffaripour S, Hynes RO, Ruggeri ZM, Wagner DD (2000) Platelets adhere to and translocate on von Willebrand factor presented by endothelium in stimulated veins. Blood 96:3322-3328

2. Babinska A, Kedees MH, Athar H, Ahmed T, Batuman O, Ehrlich YH, Hussain MM, Kornecki E (2002) F11-receptor (F11R/ JAM) mediates platelet adhesion to endothelial cells: role in inflammatory thrombosis. Thromb Haemost 88:843-850

3. Baidoshvili A, Krijnen PA, Kupreishvili K, Ciurana C, Bleeker W, Nijmeijer R, Visser CA, Visser FC, Meijer CJ, Stooker W, Eijsman L, van Hinsbergh VW, Hack CE, Niessen HW, Schalkwijk CG (2006) N(epsilon)-(carboxymethyl)lysine depositions in intramyocardial blood vessels in human and rat acute myocardial infarction: a predictor or reflection of infarction? Arterioscler Thromb Vasc Biol 26:2497-2503. doi:10.1161/01. ATV.0000245794.45804.ab

4. Ban K, Noyan-Ashraf MH, Hoefer J, Bolz SS, Drucker DJ, Husain M (2008) Cardioprotective and vasodilatory actions of glucagonlike peptide 1 receptor are mediated through both glucagon-like peptide 1 receptor-dependent and -independent pathways. Circulation 117:2340-2350. doi:10.1161/CIRCULATIONAHA.107. 739938
5. Banfi C, Brioschi M, Barbieri SS, Eligini S, Barcella S, Tremoli E, Colli S, Mussoni L (2009) Mitochondrial reactive oxygen species: a common pathway for PAR1- and PAR2-mediated tissue factor induction in human endothelial cells. J Thromb Haemost 7:206-216. doi:10.1111/j.1538-7836.2008.03204.x

6. Baroldi G, Marzilli M, L'Abbate A, Arbustini E (1990) Coronary occlusion: cause or consequence of acute myocardial infarction? Clin Cardiol 13:49-54. doi:10.1002/clc.4960130109

7. Barrabes JA, Garcia-Dorado D, Mirabet M, Inserte J, Agullo L, Soriano B, Massaguer A, Padilla F, Lidon RM, Soler-Soler J (2005) Antagonism of selectin function attenuates microvascular platelet deposition and platelet-mediated myocardial injury after transient ischemia. J Am Coll Cardiol 45:293-299. doi: 10.1016/j.jacc.2004.09.068

8. Begieneman MP, van de Goot FR, Krijnen PA, Fritz J, Paulus WJ, Spreeuwenberg MD, van Hinsbergh VW, Niessen HW (2009) The basement membrane of intramyocardial capillaries is thickened in patients with acute myocardial infarction. J Vasc Res 47:54-60. doi:10.1159/000231721

9. Bolognese L, Carrabba N, Parodi G, Santoro GM, Buonamici P, Cerisano G, Antoniucci D (2004) Impact of microvascular dysfunction on left ventricular remodeling and long-term clinical outcome after primary coronary angioplasty for acute myocardial infarction. Circulation 109:1121-1126. doi:10.1161/01.CIR. 0000118496.44135.A7

10. Boonacker E, Van Noorden CJ (2003) The multifunctional or moonlighting protein CD26/DPPIV. Eur J Cell Biol 82:53-73. doi:10.1078/0171-9335-00302

11. Carroll NM, Elaraj DM, Puhlmann M, Weinreich DM, Turner $\mathrm{EM}, \mathrm{Xu} \mathrm{H}$, Alexander HR Jr (2004) Alterations in tumor necrosis factor-induced endothelial cell procoagulant activity by hyperthermia. Int J Cancer 111:457-462. doi:10.1002/ijc.20272

12. Chong AJ, Pohlman TH, Hampton CR, Shimamoto A, Mackman N, Verrier ED (2003) Tissue factor and thrombin mediate myocardial ischemia-reperfusion injury. Ann Thorac Surg 75:S649S655

13. Cunningham MA, Romas $P$, Hutchinson $P$, Holdsworth SR, Tipping PG (1999) Tissue factor and factor VIIa receptor/ligand interactions induce proinflammatory effects in macrophages. Blood 94:3413-3420

14. Drake TA, Morrissey JH, Edgington TS (1989) Selective cellular expression of tissue factor in human tissues. Implications for disorders of hemostasis and thrombosis. Am J Pathol 134:1087-1097

15. Drucker DJ (2007) Dipeptidyl peptidase-4 inhibition and the treatment of type 2 diabetes: preclinical biology and mechanisms of action. Diabetes Care 30:1335-1343. doi:10.2337/dc07-0228

16. Essayagh S, Xuereb JM, Terrisse AD, Tellier-Cirioni L, Pipy B, Sie P (2007) Microparticles from apoptotic monocytes induce transient platelet recruitment and tissue factor expression by cultured human vascular endothelial cells via a redox-sensitive mechanism. Thromb Haemost 98:831-837. doi:10.1160/ TH07-02-0082

17. Ettelaie C, Li C, Collier ME, Pradier A, Frentzou GA, Wood CG, Chetter IC, McCollum PT, Bruckdorfer KR, James NJ (2007) Differential functions of tissue factor in the trans-activation of cellular signalling pathways. Atherosclerosis 194:88-101. doi: 10.1016/j.atherosclerosis.2006.10.010

18. Galiuto L, Garramone B, Scara A, Rebuzzi AG, Crea F, La TG, Funaro S, Madonna M, Fedele F, Agati L (2008) The extent of microvascular damage during myocardial contrast echocardiography is superior to other known indexes of post-infarct reperfusion in predicting left ventricular remodeling: results of the multicenter AMICI study. J Am Coll Cardiol 51:552-559. doi: 10.1016/j.jacc.2007.09.051

19. Gebhard C, Akhmedov A, Mocharla P, Angstenberger J, Sahbai S, Camici GG, Luscher TF, Tanner FC (2010) PDGF-CC induces 
tissue factor expression: role of PDGF receptor alpha/beta. Basic Res Cardiol 105:349-356. doi:10.1007/s00395-008-0757-5

20. Gebhard C, Stampfli SF, Gebhard CE, Akhmedov A, Breitenstein A, Camici GG, Holy EW, Luscher TF, Tanner FC (2009) Guggulsterone, an anti-inflammatory phytosterol, inhibits tissue factor and arterial thrombosis. Basic Res Cardiol 104:285-294. doi: 10.1007/s00395-009-0060-0

21. Golino P, Ragni M, Cirillo P, Avvedimento VE, Feliciello A, Esposito N, Scognamiglio A, Trimarco B, Iaccarino G, Condorelli M, Chiariello M, Ambrosio G (1996) Effects of tissue factor induced by oxygen free radicals on coronary flow during reperfusion. Nat Med 2:35-40. doi:10.1038/nm0196-35

22. Golino P, Ragni M, Cirillo P, Scognamiglio A, Ravera A, Buono C, Guarino A, Piro O, Lambiase C, Botticella F, Ezban M, Condorelli M, Chiariello M (2000) Recombinant human, active site-blocked factor VIIa reduces infarct size and no-reflow phenomenon in rabbits. Am J Physiol Heart Circ Physiol 278:H1507-H1516

23. Gorrell MD (2005) Dipeptidyl peptidase IV and related enzymes in cell biology and liver disorders. Clin Sci (Lond) 108:277-292. doi: $10.1042 / C S 20040302$

24. Heusch G, Kleinbongard P, Bose D, Levkau B, Haude M, Schulz R, Erbel R (2009) Coronary microembolization: from bedside to bench and back to bedside. Circulation 120:1822-1836. doi: 10.1161/CIRCULATIONAHA.109.888784

25. Heymann E, Mentlein R (1982) A negative blood-clotting factor lining the vessels. Naturwissenschaften 69:189-191

26. Huang J, Roth R, Heuser JE, Sadler JE (2009) Integrin alpha(v)beta(3) on human endothelial cells binds von Willebrand factor strings under fluid shear stress. Blood 113:1589-1597. doi: 10.1182/blood-2008-05-158584

27. Huisamen B, Genis A, Marais E, Lochner A (2011) Pre-treatment with a DPP-4 inhibitor is infarct sparing in hearts from obese, pre-diabetic rats. Cardiovasc Drugs Ther 25:13-20. doi: 10.1007/s10557-010-6271-7

28. Ihm SH, Chang K, Kim HY, Baek SH, Youn HJ, Seung KB, Kim JH (2010) Peroxisome proliferator-activated receptor-gamma activation attenuates cardiac fibrosis in type 2 diabetic rats: the effect of rosiglitazone on myocardial expression of receptor for advanced glycation end products and of connective tissue growth factor. Basic Res Cardiol 105:399-407. doi:10.1007/s00395-0090071-x

29. Ito H (2006) No-reflow phenomenon and prognosis in patients with acute myocardial infarction. Nat Clin Pract Cardiovasc Med 3:499-506. doi:10.1038/ncpcardio0632

30. Jacobi J, Kristal B, Chezar J, Shaul SM, Sela S (2005) Exogenous superoxide mediates pro-oxidative, proinflammatory, and procoagulatory changes in primary endothelial cell cultures. Free Radic Biol Med 39:1238-1248. doi:10.1016/j.freeradbiomed.2005. 06.010

31. Jaffe R, Dick A, Strauss BH (2010) Prevention and treatment of microvascular obstruction-related myocardial injury and coronary no-reflow following percutaneous coronary intervention: a systematic approach. JACC Cardiovasc Interv 3:695-704. doi: 10.1016/j.jcin.2010.05.004

32. Kleinbongard P, Bose D, Baars T, Mohlenkamp S, Konorza T, Schoner S, Elter-Schulz M, Eggebrecht H, Degen H, Haude M, Levkau B, Schulz R, Erbel R, Heusch G (2011) Vasoconstrictor potential of coronary aspirate from patients undergoing stenting of saphenous vein aortocoronary bypass grafts and its pharmacological attenuation. Circ Res 108:344-352. doi: 10.1161/CIRCRESAHA.110.235713

33. Kleinbongard P, Heusch G, Schulz R (2010) TNFalpha in atherosclerosis, myocardial ischemia/reperfusion and heart failure. Pharmacol Ther 127:295-314. doi:10.1016/j.pharmthera.2010. 05.002
34. Koyama T, Gao M, Ueda T, Batra S, Itoh $\mathrm{K}$, Ushiki T, Abe $\mathrm{K}$ (1997) Different enzyme activities in coronary capillary endothelial cells. Adv Exp Med Biol 411:359-364

35. Ku HC, Chen WP, Su MJ (2011) DPP4 deficiency preserves cardiac function via GLP-1 signaling in rats subjected to myocardial ischemia/reperfusion. Naunyn Schmiedebergs Arch Pharmacol 384:197-207. doi:10.1007/s00210-011-0665-3

36. Lagrand WK, Niessen HW, Wolbink GJ, Jaspars LH, Visser CA, Verheugt FW, Meijer CJ, Hack CE (1997) C-reactive protein colocalizes with complement in human hearts during acute myocardial infarction. Circulation 95:97-103. doi:10.1161/01. CIR.95.1.97

37. Lee EW, Michalkiewicz M, Kitlinska J, Kalezic I, Switalska H, Yoo P, Sangkharat A, Ji H, Li L, Michalkiewicz T, Ljubisavljevic M, Johansson H, Grant DS, Zukowska Z (2003) Neuropeptide Y induces ischemic angiogenesis and restores function of ischemic skeletal muscles. J Clin Invest 111:1853-1862. doi:10.1172/ JCI200316929

38. Li S, Zhong S, Zeng K, Luo Y, Zhang F, Sun X, Chen L (2010) Blockade of NF-kappaB by pyrrolidine dithiocarbamate attenuates myocardial inflammatory response and ventricular dysfunction following coronary microembolization induced by homologous microthrombi in rats. Basic Res Cardiol 105: 139-150. doi:10.1007/s00395-009-0067-6

39. Luo AK, Wu KC (2006) Imaging microvascular obstruction and its clinical significance following acute myocardial infarction. Heart Fail Rev 11:305-312. doi:10.1007/s10741006-0231-0

40. Lupia E, Spatola T, Cuccurullo A, Bosco O, Mariano F, Pucci A, Ramella R, Alloatti G, Montrucchio G (2010) Thrombopoietin modulates cardiac contractility in vitro and contributes to myocardial depressing activity of septic shock serum. Basic Res Cardiol 105:609-620. doi:10.1007/s00395-010-0103-6

41. Mackman N (2009) The many faces of tissue factor. J Thromb Haemost 7 Suppl 1:136-139. doi:10.1111/j.1538-7836.2009. 03368.x

42. Mentlein R, Heymann E (1982) Dipeptidyl peptidase IV inhibits the polymerization of fibrin monomers. Arch Biochem Biophys 217:748-750

43. Miyoshi T, Yamashita K, Arai T, Yamamoto K, Mizugishi K, Uchiyama $\mathrm{T}$ (2010) The role of endothelial interleukin-8/NADPH oxidase 1 axis in sepsis. Immunology 131:331-339. doi: 10.1111/j.1365-2567.2010.03303.x

44. Oeseburg H, de Boer RA, Buikema H, van der HP, van Gilst WH, Sillje HH (2010) Glucagon-like peptide 1 prevents reactive oxygen species-induced endothelial cell senescence through the activation of protein kinase A. Arterioscler Thromb Vasc Biol 30:1407-1414. doi:10.1161/ATVBAHA.110.206425

45. Park Y, Yang J, Zhang H, Chen X, Zhang C (2011) Effect of PAR2 in regulating TNF-alpha and $\mathrm{NAD}(\mathrm{P}) \mathrm{H}$ oxidase in coronary arterioles in type 2 diabetic mice. Basic Res Cardiol 106:111-123. doi:10.1007/s00395-010-0129-9

46. Rezkalla SH, Kloner RA (2002) No-reflow phenomenon. Circulation 105:656-662. doi:10.1161/hc0502.102867

47. Sauve M, Ban K, Momen MA, Zhou YQ, Henkelman RM, Husain M, Drucker DJ (2010) Genetic deletion or pharmacological inhibition of dipeptidyl peptidase-4 improves cardiovascular outcomes after myocardial infarction in mice. Diabetes 59:1063-1073. doi:10.2337/db09-0955

48. Takasawa W, Ohnuma K, Hatano R, Endo Y, Dang NH, Morimoto C (2010) Inhibition of dipeptidyl peptidase 4 regulates microvascular endothelial growth induced by inflammatory cytokines. Biochem Biophys Res Commun 401:7-12. doi: 10.1016/j.bbrc.2010.08.112

49. Verheul HM, Jorna AS, Hoekman K, Broxterman HJ, Gebbink MF, Pinedo HM (2000) Vascular endothelial growth factor- 
stimulated endothelial cells promote adhesion and activation of platelets. Blood 96:4216-4221

50. Ye Y, Keyes KT, Zhang C, Perez-Polo JR, Lin Y, Birnbaum Y (2010) The myocardial infarct size-limiting effect of sitagliptin is PKA-dependent, whereas the protective effect of pioglitazone is partially dependent on PKA. Am J Physiol Heart Circ Physiol 298:H1454-H1465. doi:10.1152/ajpheart.00867.2009

51. Zhang C, Wu J, Xu X, Potter BJ, Gao X (2010) Direct relationship between levels of TNF-alpha expression and endothelial dysfunction in reperfusion injury. Basic Res Cardiol 105:453-464. doi:10.1007/s00395-010-0083-6
52. Zukowska Z, Grant DS, Lee EW (2003) Neuropeptide Y: a novel mechanism for ischemic angiogenesis. Trends Cardiovasc Med 13:86-92. doi:10.1016/S1050-1738(02)00232-3

53. Zwaginga JJ, de Boer HC, IJsseldijk MJ, Kerkhof A, MullerBerghaus G, Gruhlichhenn J, Sixma JJ, de Groot PG (1990) Thrombogenicity of vascular cells. Comparison between endothelial cells isolated from different sources and smooth muscle cells and fibroblasts. Arteriosclerosis 10:437-448. doi: 10.1161/01.ATV.10.3.437 